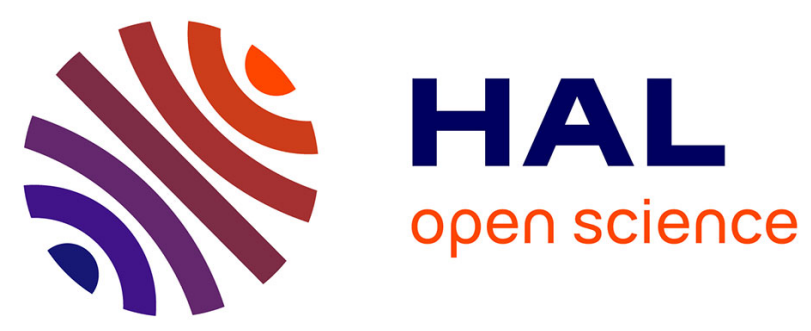

\title{
Chicken cathelicidin-2-derived peptides with enhanced immunomodulatory and antibacterial activities against biological warfare agents
}

\author{
E. Margo Molhoek, Albert van Dijk, Edwin J.A. Veldhuizen, Helma \\ Dijk-Knijnenburg, Roos H. Mars-Groenendijk, Linda C.L. Boele, Wendy E. \\ Kaman-Van Zanten, Henk P. Haagsman, Floris J. Bikker
}

\section{To cite this version:}

E. Margo Molhoek, Albert van Dijk, Edwin J.A. Veldhuizen, Helma Dijk-Knijnenburg, Roos H. Mars-Groenendijk, et al.. Chicken cathelicidin-2-derived peptides with enhanced immunomodulatory and antibacterial activities against biological warfare agents. International Journal of Antimicrobial Agents, 2010, 36 (3), pp.271. 10.1016/j.ijantimicag.2010.06.001 . hal-00608992

\section{HAL Id: hal-00608992 https://hal.science/hal-00608992}

Submitted on 17 Jul 2011

HAL is a multi-disciplinary open access archive for the deposit and dissemination of scientific research documents, whether they are published or not. The documents may come from teaching and research institutions in France or abroad, or from public or private research centers.
L'archive ouverte pluridisciplinaire HAL, est destinée au dépôt et à la diffusion de documents scientifiques de niveau recherche, publiés ou non, émanant des établissements d'enseignement et de recherche français ou étrangers, des laboratoires publics ou privés. 


\section{Accepted Manuscript}

Title: Chicken cathelicidin-2-derived peptides with enhanced immunomodulatory and antibacterial activities against biological warfare agents

Authors: E. Margo Molhoek, Albert van Dijk, Edwin J.A.

Veldhuizen, Helma Dijk-Knijnenburg, Roos H.

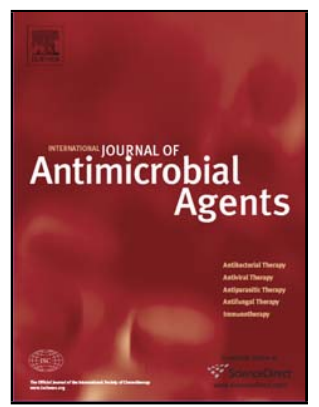

Mars-Groenendijk, Linda C.L. Boele, Wendy E. Kaman-van

Zanten, Henk P. Haagsman, Floris J. Bikker

PII: $\quad$ S0924-8579(10)00238-4

DOI: $\quad$ doi:10.1016/j.ijantimicag.2010.06.001

Reference: $\quad$ ANTAGE 3336

To appear in: International Journal of Antimicrobial Agents

Received date: $\quad 23-4-2010$

Revised date: $\quad 25-5-2010$

Accepted date: $\quad 2-6-2010$

Please cite this article as: Molhoek EM, van Dijk A, Veldhuizen EJA, DijkKnijnenburg H, Mars-Groenendijk RH, Boele LCL, Zanten WEK-v, Haagsman HP, Bikker FJ, Chicken cathelicidin-2-derived peptides with enhanced immunomodulatory and antibacterial activities against biological warfare agents, International Journal of Antimicrobial Agents (2008), doi:10.1016/j.ijantimicag.2010.06.001

This is a PDF file of an unedited manuscript that has been accepted for publication. As a service to our customers we are providing this early version of the manuscript. The manuscript will undergo copyediting, typesetting, and review of the resulting proof before it is published in its final form. Please note that during the production process errors may be discovered which could affect the content, and all legal disclaimers that apply to the journal pertain. 


\section{Chicken cathelicidin-2-derived peptides with enhanced immunomodulatory and antibacterial activities against biological warfare agents}

E. Margo Molhoek ${ }^{\mathrm{a}, \mathrm{b}}$, Albert van Dijk ${ }^{\mathrm{b}}$, Edwin J.A. Veldhuizen ${ }^{\mathrm{b}}$, Helma Dijk-

Knijnenburg ${ }^{a}$, Roos H. Mars-Groenendijk ${ }^{a}$, Linda C.L. Boele ${ }^{a}$, Wendy E. Kaman-van Zanten $^{a}$, Henk P. Haagsman ${ }^{b, *}$, Floris J. Bikker ${ }^{c}$

a TNO Defence, Security and Safety, Rijswijk, The Netherlands

${ }^{\mathrm{b}}$ Department of Infectious Diseases and Immunology, Faculty of Veterinary Medicine, Utrecht University, Yalelaan 1, 3584 CL Utrecht, The Netherlands

${ }^{c}$ Department of Oral Biochemistry, Academic Centre for Dentistry Amsterdam (ACTA), Vrije Universiteit and Universiteit van Amsterdam, Amsterdam, The Netherlands

\section{ARTICLE INFO}

Article history:

Received 23 April 2010

Accepted 2 June 2010

Keywords:

Host defence peptide

Cathelicidin

Antibacterial activity 


\section{Cytotoxicity}

Immunomodulatory activity

Biological warfare agents

* Corresponding author. Tel.: +31 3025353 54; fax: +31 302532333.

E-mail address: h.p.haagsman@uu.nl (H.P. Haagsman). 


\section{ABSTRACT}

Host defence peptides (HDPs) are considered to be excellent candidates for the development of novel therapeutic agents. Recently, it was demonstrated that the peptide C1-15, an $\mathrm{N}$-terminal segment of chicken HDP cathelicidin-2, exhibits potent antibacterial activity while lacking cytotoxicity towards eukaryotic cells. In the present study, we report that $\mathrm{C} 1-15$ is active against bacteria such as Bacillus anthracis and Yersinia pestis that may potentially be used by bioterrorists. Substitution of single and multiple phenylalanine (Phe) residues to tryptophan (Trp) in C1-15 resulted in variants with improved antibacterial activity against $B$. anthracis and $Y$. pestis as well as decreased salt sensitivity. In addition, these peptides exhibited enhanced neutralisation of lipopolysaccharide (LPS)-induced release of pro-inflammatory cytokines in human peripheral blood mononuclear cells (PBMCs). The antibacterial and LPS-neutralising activities of these $\mathrm{C1}$-15-derived peptides are exerted at concentrations far below the concentrations that are toxic to human PBMCs. Taken together, we show that Phe $\rightarrow$ Trp substitutions in $\mathrm{C} 1-15$ variants enhances the antibacterial and LPS-neutralising activities against pathogenic bacteria, including those that may potentially be used as biological warfare agents. 


\section{Introduction}

Exposure to biological warfare agents may cause a highly progressive, acute infection that may be lethal in some forms. In these cases, use of broad-spectrum antibiotics might be life saving. In addition, the number of antibiotic-resistant microorganisms is increasing, underlining the growing need for novel antimicrobial compounds.

Host defence peptides (HDPs) are excellent candidates for the development of novel broad-spectrum antibiotics. In general, HDPs exhibit potent broad-spectrum antibacterial and/or immunomodulatory properties. Moreover, HDPs have a low tendency to select resistant strains $[1,2]$.

We previously demonstrated that the $N$-terminal fragment of the HDP chicken cathelicidin-2 (CATH-2), namely the peptide $\mathrm{C} 1-15$, possesses broad-spectrum antibacterial activity while being non-haemolytic against erythrocytes and is therefore a promising lead for the development of novel antimicrobial drugs with broad-spectrum activity [3].

In this study, we explored the use of $\mathrm{C} 1-15$ as a potential novel lead compound to combat biowarfare agents. In doing so, we aimed at broadening the antibacterial activity of $\mathrm{C} 1-15$ by substitution of phenylalanine (Phe) residues on the non-polar face by tryptophan (Trp) residues. The antibacterial activity and toxicity against human peripheral blood mononuclear cells (PBMCs) of C1-15 variants were evaluated. In addition, the anti-inflammatory activity of $\mathrm{C} 1-15$ variants was examined. 


\section{Material and methods}

\subsection{Peptide synthesis}

C1-15 (RFGRFLRKIRRFRPK) and the C1-15 variants F2W (RWGRFLRKIRRFRPK), F5W (RFGRWLRKIRRFRPK), F12W (RFGRFLRKIRRWRPK) and F2,5,12W (RWGRWLRKIRRWRPK) were synthesised by Fmoc chemistry using a SYRO peptide synthesiser (MultiSynTech, Bochum, Germany) as described by Bikker et al. [4].

\subsection{Antibacterial activity}

The antimicrobial activity of $\mathrm{C} 1-15$ variants was evaluated against Gram-positive Bacillus anthracis Vollum strain ATCC 14578 (American Type Culture Collection, Manassas, VA) and meticillin-resistant Staphylococcus aureus (MRSA) ATCC 43300 as well as against the Gram-negative virulent Yersinia pestis NCTC 08775 (National Collection of Type Cultures, London, UK) and Vibrio cholerae (clinical isolate, Slotervaart Hospital, Amsterdam, The Netherlands). All bacteria were grown and maintained in tryptic soy broth (TSB) (bioTRADING, Mijdrecht, The Netherlands) under aerobic conditions at $35^{\circ} \mathrm{C}\left(B\right.$. anthracis, MRSA and $V$. cholera) or $26^{\circ} \mathrm{C}$ (Y. pestis). The antimicrobial activity of $\mathrm{C} 1-15$ and $\mathrm{C} 1-15$ variants was determined using colony counting assays as described previously [3]. 


\subsection{Isolation and culture of peripheral blood mononuclear cells}

Human PBMCs were isolated from buffy coats (Sanquin, Rotterdam, The Netherlands) as reported previously [3] and were seeded at $0.5 \times 10^{6}$ cells/well into a Corning Costar 96-well flat-bottom culture plate (Corning Inc., Corning, NY) in RPMI-1640 (Lonza BioWhittaker, Basel, Switzerland) supplemented with 10\% heat-inactivated fetal bovine serum (FBS) (FBS Gold; PAA, Pasching, Austria), $100 \mathrm{U} / \mathrm{mL}$ penicillin and $100 \mu \mathrm{g} / \mathrm{mL}$ streptomycin (Lonza BioWhittaker).

\subsection{Cytotoxicity assay}

The toxic effect of C1-15 variants on PBMCs was evaluated using WST reagents (Roche Diagnostics, Mannheim, Germany). Cells were incubated for $24 \mathrm{~h}$ with culture medium and $\mathrm{C} 1-15$ variants at $37{ }^{\circ} \mathrm{C}$ and $5 \% \mathrm{CO}_{2}$. Following centrifugation, supernatants were removed and $100 \mu \mathrm{L}$ of fresh RPMI- 1640 supplemented with $10 \%$ FBS and $10 \mu \mathrm{L}$ of WST-1 reagents was added and the cells were further incubated. After 60 min incubation time, absorbance was determined at $450 \mathrm{~nm}$, with a reference wavelength at $650 \mathrm{~nm}$.

2.5. Neutralisation of the lipopolysaccharide (LPS)-induced cytokine response by C1-15 variants

PBMCs were used to study the modulation of LPS-induced cytokine secretion by C1-15 variants. PBMCs were stimulated with $1 \mathrm{ng} / \mathrm{mL}$ ultrapure LPS from Escherichia coli O111:B4 (InvivoGen, San Diego, CA) for $24 \mathrm{~h}$ in the absence or presence of various 
concentrations of $\mathrm{C} 1-15$ variants. Following incubation, cell culture supernatants were collected and stored at $-20^{\circ} \mathrm{C}$ until further analysis.

\subsection{Cytokine measurements}

Levels of interleukin (IL)- 6 were determined by enzyme-linked immunosorbent assay (ELISA) using the commercial PeliKine Compact ${ }^{\mathrm{TM}}$ Human ELISA Kit (Sanquin, Amsterdam, The Netherlands) following the manufacturer's recommendations.

\subsection{LPS binding by C1-15 variants}

C1-15 variants were examined for LPS-neutralising activity in a limulus amoebocyte lysate (LAL) assay. Briefly, $25 \mu \mathrm{L}$ of peptide at concentrations from 0 to $20 \mu \mathrm{M}$ diluted in RPMI-1640 (Lonza BioWhittaker) were incubated with $25 \mu \mathrm{L}$ of a $2 \mathrm{ng} / \mathrm{mL}$ ultrapure LPS from E. coli $\mathrm{O} 111: \mathrm{B} 4$ (InvivoGen) for $60 \mathrm{~min}$ at $37^{\circ} \mathrm{C}$ in a 96 -well endotoxin-free plate (Hycult Biotechnology, Uden, The Netherlands). Residual LPS activity was detected using the LAL assay according to the manufacturer's recommendations (Hycult Biotechnology).

\subsection{Statistical analysis}

Statistical significance was determined by two-way analysis of variance (ANOVA) followed by post hoc testing by the Bonferroni method. A $P$-value of $<0.05$ was considered statistically significant. Values shown are expressed as mean \pm standard error of the mean. 


\section{Results}

\subsection{Antibacterial activity of $\mathrm{C} 1-15$ and $\mathrm{C1}-15$ variants}

The $\mathrm{N}$-terminal segment of CATH-2, peptide $\mathrm{C} 1-15$, affected the survival of all tested bacteria (Fig. 1)

To enhance the antimicrobial activity of $\mathrm{C} 1-15$, a panel of $\mathrm{C} 1-15$ variants with $\mathrm{Phe} \rightarrow \operatorname{Trp}$ substitutions was designed. In comparison with Phe, Trp contains a more bulky hydrophobic side chain consisting of an indole chain. Since there are three Phe residues on the non-polar face of $\mathrm{C} 1-15$, variants were synthesised with Phe $\rightarrow \operatorname{Trp}$ substitutions at positions 2 (F2W), 5 (F5W) and $12(\mathrm{~F} 12 \mathrm{~W})$. In addition, a triple Phe $\rightarrow$ Trp variant was synthesised $(\mathrm{F} 2,5,12 \mathrm{~W})$.

Compared with C1-15, a single Phe $\rightarrow$ Trp substitution (F2W, F5W and F12W) improved the antibacterial activity against $Y$. pestis and $B$. anthracis. Survival of $Y$. pestis was reduced with $50 \%$ by $5 \mu \mathrm{M}$ F2W, F5W or F12W compared with $20 \mu \mathrm{M}$ for $\mathrm{C} 1-15$ (Fig. 1B). Moreover, $2 \mu \mathrm{M}$ of $\mathrm{F} 2 \mathrm{~W}, \mathrm{~F} 5 \mathrm{~W}$ or $\mathrm{F} 12 \mathrm{~W}$ led to a $50 \%$ decline in $B$. anthracis survival compared with $4 \mu \mathrm{M}$ for $\mathrm{C} 1-15$ (Fig. $1 \mathrm{AD}$. Antibacterial activity against $Y$. pestis and $B$. anthracis was further improved by multiple substitutions, with $2.5 \mu \mathrm{M}$ and $1 \mu \mathrm{M}$, respectively, of F2,5,12W needed to reduce the survival of the bacteria by $50 \%$ (Fig. $1 A, D$. 


\subsection{Antibacterial activity in the presence of salts}

The antibacterial activity of CATH-2 against MRSA was not affected by $100 \mathrm{mM} \mathrm{NaCl}$ (data not shown). However, C1-15 lost its antibacterial activity in the presence of 100 $\mathrm{mM} \mathrm{NaCl}$. Even the highest peptide concentration used $(40 \mu \mathrm{M})$ could only reduce the survival by 1 log unit. However, Trp substitutions resulting in F2,5,12W partly restored the antibacterial activity in the presence of $\mathrm{NaCl}$ (Fig. 2).

\subsection{Cytotoxicity of $\mathrm{C} 1-15$ variants}

C1-15 variants were evaluated for their toxicity to human PBMCs with and without the presence of $10 \%$ FBS. Cytotoxicity of C1-15 to PBMCs in the presence of FBS was negligible. Substitution of Phe by Trp residues increased the cytotoxicity to PBMCs up to $75 \%$ at $40 \mu \mathrm{M}$ after multiple substitutions (F2,5,12W) (Fig. 3). Similar experiments in the absence of FBS showed that FBS only had a marginal protective effect against peptide cytotoxicity (data not shown).

\subsection{Neutralisation of the LPS-induced cytokine response}

PBMCs were stimulated with LPS in the presence of various concentrations of C1-15 variants. The concentration of the pro-inflammatory mediator IL-6 was measured in culture supernatants (Fig. 4A).

Substitution of Phe residues in $\mathrm{C} 1-15$ by Trp residues improved the LPS-neutralising capacity by improving inhibition of the LPS-induced release of IL-6. Multiple Phe $\rightarrow$ Trp 
substitutions in C1-15 resulted in even higher LPS-neutralising activity; $10 \mu \mathrm{M}$ of F2,5,12W significantly inhibited $85 \%$ of the IL-6 LPS response (Fig. 4A).

\subsection{LPS binding by C1-15 variants}

To verify whether the improved LPS-neutralising activities of $\mathrm{C} 1-15$ variants could be contributed to improved LPS binding, C1-15 variants were evaluated for their ability to bind LPS in a LAL assay. Phe $\rightarrow$ Trp substitution in C1-15 enhanced the LPS-binding capacity of the peptides (Fig. 4B).

\section{Discussion}

During military operations or bioterrorist attacks, immediate diagnosis or identification of the bacterial agent is not always possible. In case of exposure from an unknown source, the availability and usability of broad-spectrum antimicrobials can be vital. Furthermore, owing to the use and misuse of current antimicrobials, growing numbers of multiresistant bacteria have arisen, including those that might potentially be used for offensive purposes, implying that there is a need for new broad-spectrum antimicrobials.

Recently, it was reported that the HDP C1-15, a truncated variant of CATH-2, possesses strong broad-spectrum antibacterial activity. In addition, this peptide is non-haemolytic against erythrocytes [3]. In this study, we extended the earlier reported broad antibacterial activity with more bacteria, including bacteria often related to bioterrorist 
attacks (B. anthracis, $V$. cholera and $Y$. pestis). In addition, we aimed to enhance the antibacterial activity of $\mathrm{C} 1-15$ by substituting Phe residues by Trp residues.

Substitutions of $\mathrm{C} 1-15$ Phe to Trp residues resulted in a peptide containing a large number of Arg and Trp residues. Previously it was reported by others that Arg and Trp complement each other well for the purpose of antimicrobial activity [5]. The cationic charge of Arg provides an effective means of attraction of the peptides to the target membranes, and hydrogen bonding facilitates the interaction with the negatively charged surfaces of bacterial membranes. The hydrophobic bulk of Trp residues play a role in membrane association because it preferentially interacts with the interfacial region of membranes [6]. In combination, Arg and Trp residues are capable of participating in stronger cation- $\pi$ interactions compared with Arg and Phe residues [7]. Such interactions would facilitate deeper embedding of the peptides in the membrane and disrupt the membrane structure [5].

In line with these data, we observed that single Phe substitutions (F2W, F5W and F12W) augmented the antibacterial activity by a factor of four against $Y$. pestis and by a factor of two against $B$. anthracis. Multiple substitutions $(F 2,5,12 W)$ further enhanced antibacterial activity: the peptide was eight and four times more potent compared with C1-15 in reducing the survival of $Y$. pestis and $B$. anthracis, respectively.

The ability to resist salt is highly relevant for HDPs in order to function under physiological conditions. As reported earlier by Xiao et al. [8] and confirmed by us, 
CATH-2 is resistant to salt, but C1-15 almost completely lost its antibacterial activity in the presence of $100 \mathrm{mM} \mathrm{NaCl}$. However, we could restore the antibacterial activity in the presence of salt by Phe to Trp substitutions.

Overall, these findings show that the insertion of Trp residues can make peptides less salt-sensitive and more potent in bacterial killing.

Bacterial killing by antimicrobial compounds may cause a release of endotoxin (LPS) from Gram-negative bacteria, which subsequently might lead to an exaggerated immune response. This can result in early sepsis, in which high levels of cytokines and inflammatory mediators become destructive, causing organ failure, cardiovascular shock and even resulting in death [9]. Some HDPs are found to counteract the development of septic shock by neutralising endotoxin [10]. Although CATH-2 is able to inhibit the LPSinduced pro-inflammatory cytokine responses, the $\mathrm{N}$-terminal part, $\mathrm{C} 1-15$, showed only moderate LPS-neutralising activities [3]. Phe $\rightarrow$ Trp substitutions in C1-15, resulting in peptide F2,5,12W, significantly increased the LPS-neutralising capacity. Recently, we [11] and others [12] reported the importance of hydrophobicity in neutralising LPS cytokine responses. In line with our observations, Nan et al. [12] showed that substitution of Trp by Lys residues in the Trp-rich peptide indolicidin resulted in decreased hydrophobicity and loss of LPS-neutralising activity. Previously it was shown that inhibition of the pro-inflammatory response is mainly established by direct binding of cationic HDPs to LPS $[11,13]$. In line with these observations, we found a correlation between LPS-neutralising activities and LPS binding. 
It has been demonstrated that high concentrations of cationic HDPs containing a high amount of Trp residues may be toxic to the host [14]. In the present study, we observed that an increased number of Trp residues results in increased cytotoxicity against mammalian cells such as PBMCs. However, the Trp substitutes exerted broad antibacterial and LPS-neutralising activities at much lower concentrations than their toxic effects on human PBMCs.

In summary, we successfully increased the antibacterial activity of $\mathrm{C} 1-15$ and made it less salt sensitive by replacement of Phe by Trp residues. In addition, F2,5,12W showed good neutralising activities of LPS cytokine responses.

\section{Funding}

This work was financially supported by the V502 programme of the Dutch Ministry of Defence and the Immuno Valley ALTANT programme of the Dutch Ministry of Agriculture, Nature and Food Quality.

\section{Competing interests}

None declared.

\section{Ethical approval}

Not required. 


\section{References}

[1] Brown KL, Hancock RE. Cationic host defense (antimicrobial) peptides. Curr Opin Immunol 2006;18:24-30.

[2] Zasloff M. Antimicrobial peptides of multicellular organisms. Nature 2002;415:38995.

[3] van Dijk A, Molhoek EM, Veldhuizen EJ, van Bokhoven JL, Wagendorp E, Bikker FJ, et al. Identification of chicken cathelicidin-2 core elements involved in antibacterial and immunomodulatory activities. Mol Immunol 2009;46:2465-73.

[4] Bikker FJ, Kaman-van Zanten WE, de Vries-van de Ruit AM, Voskamp-Visser I, van Hooft PA, Mars-Groenendijk RH, et al. Evaluation of the antibacterial spectrum of drosocin analogues. Chem Biol Drug Des 2006;68:148-53.

[5] Chan DI, Prenner EJ, Vogel HJ. Tryptophan- and arginine-rich antimicrobial peptides: structures and mechanisms of action. Biochim Biophys Acta 2006;1758:1184-202.

[6] Yau WM, Wimley WC, Gawrisch K, White SH. The preference of tryptophan for membrane interfaces. Biochemistry 1998;37:14713-8.

[7] Dougherty DA. Cation-pi interactions in chemistry and biology: a new view of benzene, Phe, Tyr, and Trp. Science 1996;271:163-8.

[8] Xiao Y,Herrera AJ, Bommineni YR, Soulages JL, Prakash O, Zhang G. The central kink region of fowlicidin-2, an $\alpha$-helical host defense peptide, is critically involved in bacterial killing and endotoxin neutralization. J Innate Immun 2009;1:268-80.

[9] Cohen J. The immunopathogenesis of sepsis. Nature 2002;420:885-91. 
[10] Bowdish DM, Davidson DJ, Scott MG, Hancock RE. Immunomodulatory activities of small host defense peptides. Antimicrob Agents Chemother 2005;49:1727-32.

[11] Molhoek EM, den Hertog AL, de Vries AM, Nazmi K, Veerman EC, Hartgers FC, et al. Structure-function relationship of the human antimicrobial peptide LL-37 and LL-37 fragments in the modulation of TLR responses. Biol Chem 2009;390:295-303.

[12] Nan YH, Park KH, Park Y, Jeon YJ, Kim Y, Park IS, et al. Investigating the effects of positive charge and hydrophobicity on the cell selectivity, mechanism of action and anti-inflammatory activity of a Trp-rich antimicrobial peptide indolicidin. FEMS Microbiol Lett 2009;292:134-40.

[13] Rosenfeld Y, Papo N, Shai Y. Endotoxin (lipopolysaccharide) neutralization by innate immunity host-defense peptides. Peptide properties and plausible modes of action. J Biol Chem 2006;281:1636-43.

[14] Andrushchenko VV, Aarabi MH, Nguyen LT, Prenner EJ, Vogel HJ.

Thermodynamics of the interactions of tryptophan-rich cathelicidin antimicrobial peptides with model and natural membranes. Biochim Biophys Acta 2008;1778:1004-14. 


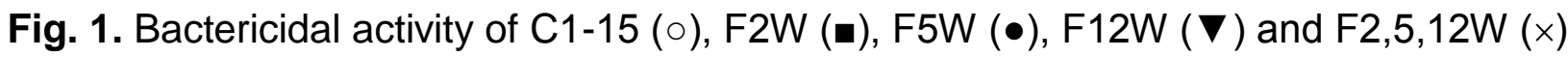
against (A) Vibrio cholera, (B) Yersinia pestis, (C) meticillin-resistant Staphylococcus aureus (MRSA) and (D) Bacillus anthracis. Each point represents the mean + standard error of the mean of at least four experiments. ${ }^{*}$ Significantly different compared with C1$15(P<0.05)$. CFU, colony-forming units.

Fig. 2. Salt sensitivity of $\mathrm{C} 1-15$ and $\mathrm{F} 2,5,12 \mathrm{~W}$ : bactericidal activity against meticillinresistant Staphylococcus aureus (MRSA) of C1-15 (०) and F2,5,12W ( $\times$ ) without salt and of $\mathrm{C} 1-15(\bullet)$ and F2,5,12W $\left(^{*}\right)$ in the presence of $100 \mathrm{mM} \mathrm{NaCl}$. CFU, colony-forming units.

Fig. 3. Cytotoxicity of $\mathrm{C} 1-15(\circ), \mathrm{F} 2 \mathrm{~W}(\mathbf{\bullet}), \mathrm{F} 5 \mathrm{~W}(\bullet), \mathrm{F} 12 \mathrm{~W}(\mathbf{\nabla})$ and $\mathrm{F} 2,5,12 \mathrm{~W}(\times)$ on human peripheral blood mononuclear cells. Each point represents the mean + standard error of the mean of three different donors. * Significantly different compared with C1-15 $(P<0.05)$.

Fig. 4. (A) Comparison of the lipopolysaccharide (LPS)-neutralising activity of C1-15 (०),

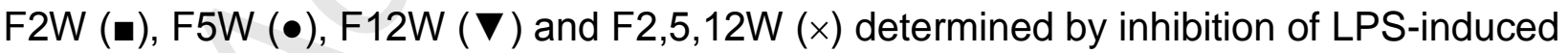
interleukin (IL)-6 release. The amount of IL-6 resulting from cells incubated with LPS alone was set to $100 \%(52.4 \pm 5.4 \mathrm{ng} / \mathrm{mL})$. (B) Limulus amoebocyte lysate assay. Each point represents the mean + standard error of the mean of three independent experiments. * Significantly different compared with $\mathrm{C} 1-15(P<0.05)$. 
Gram-negative
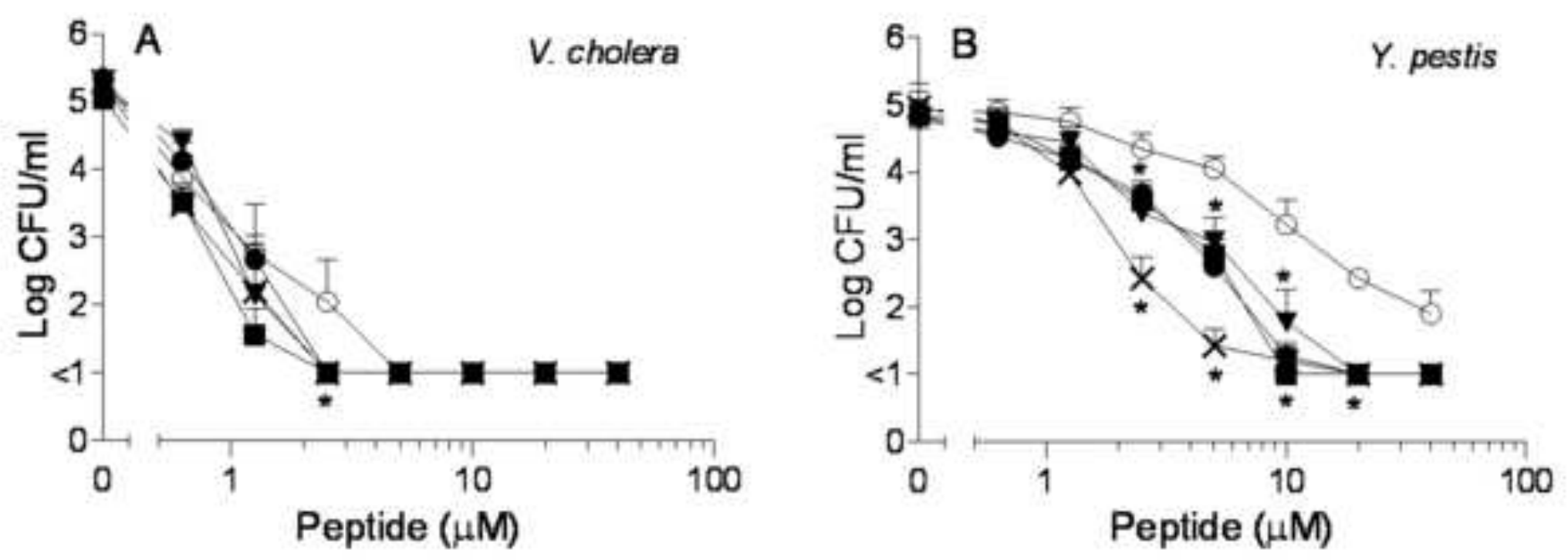

Gram-positive
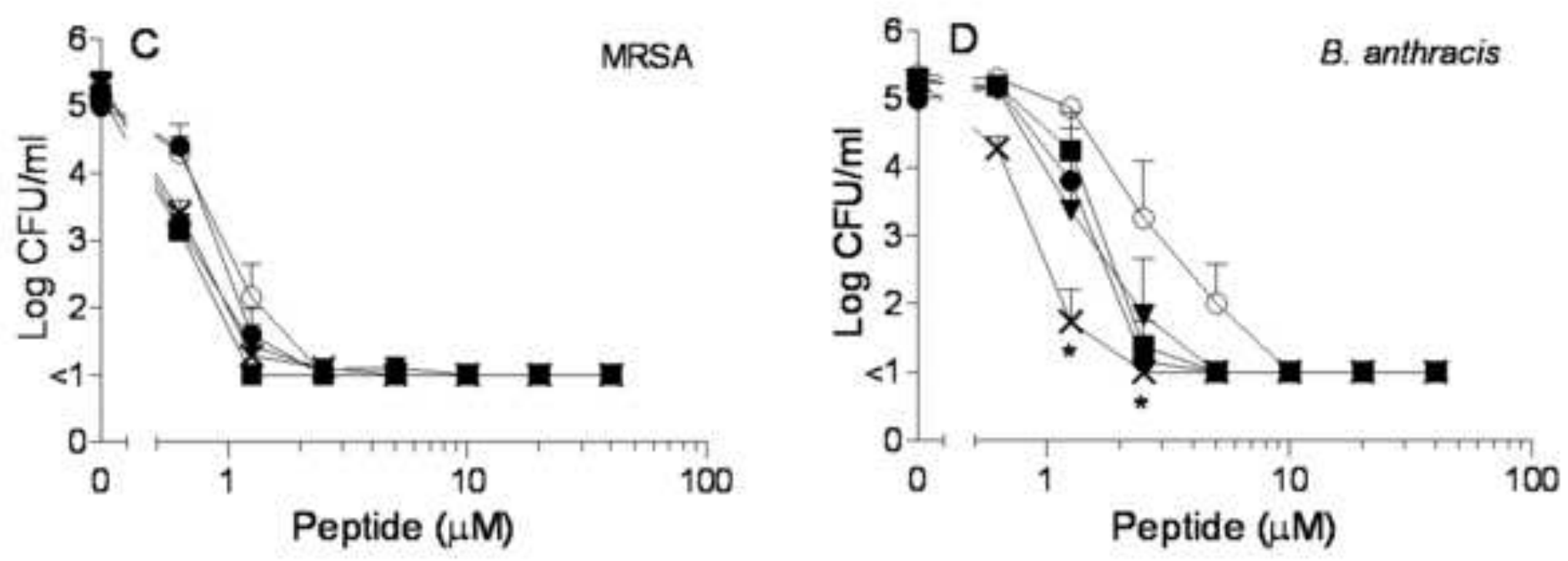

rage $1 /$ or $2 U$ 


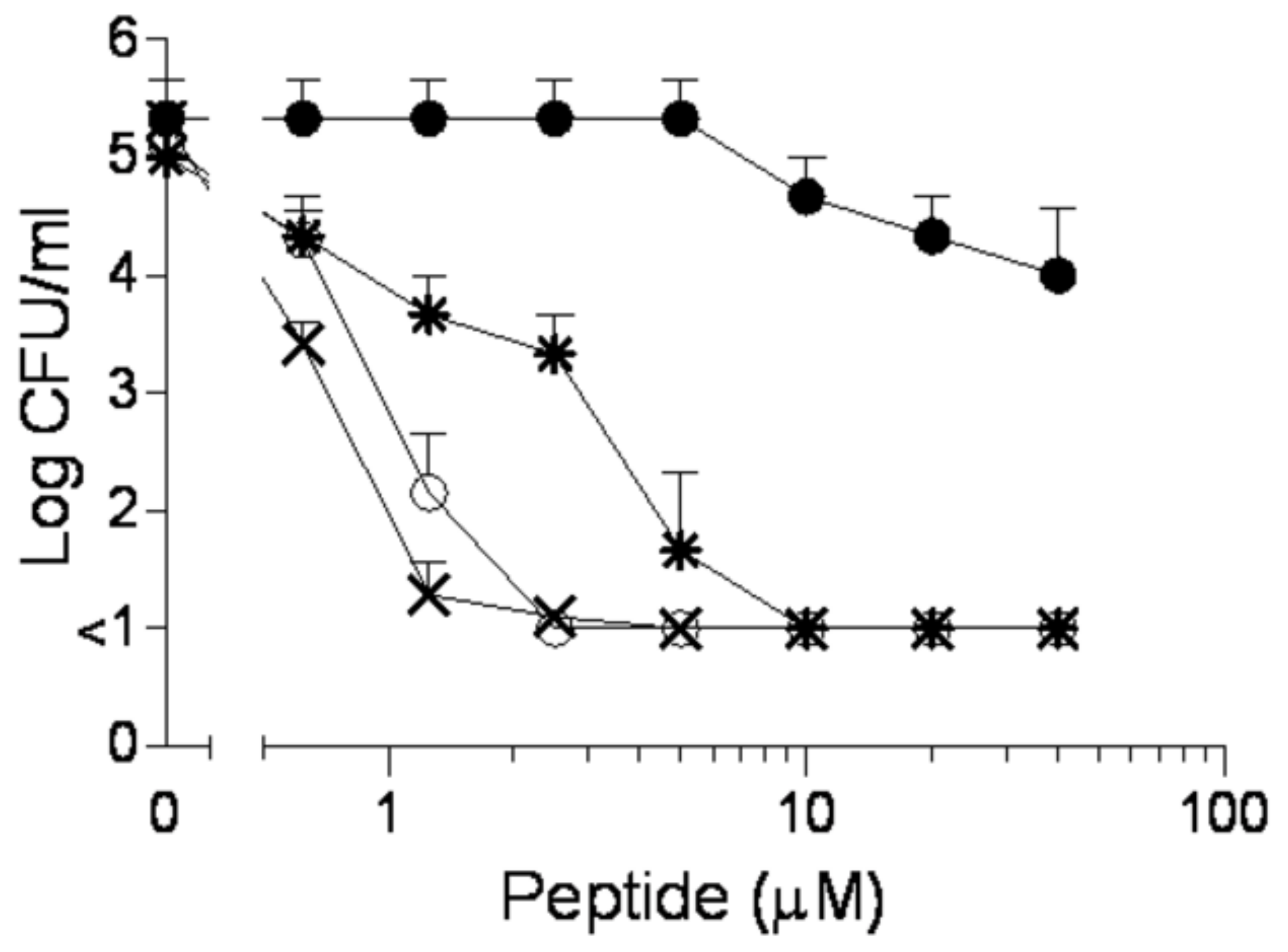

Page 18 of 20 


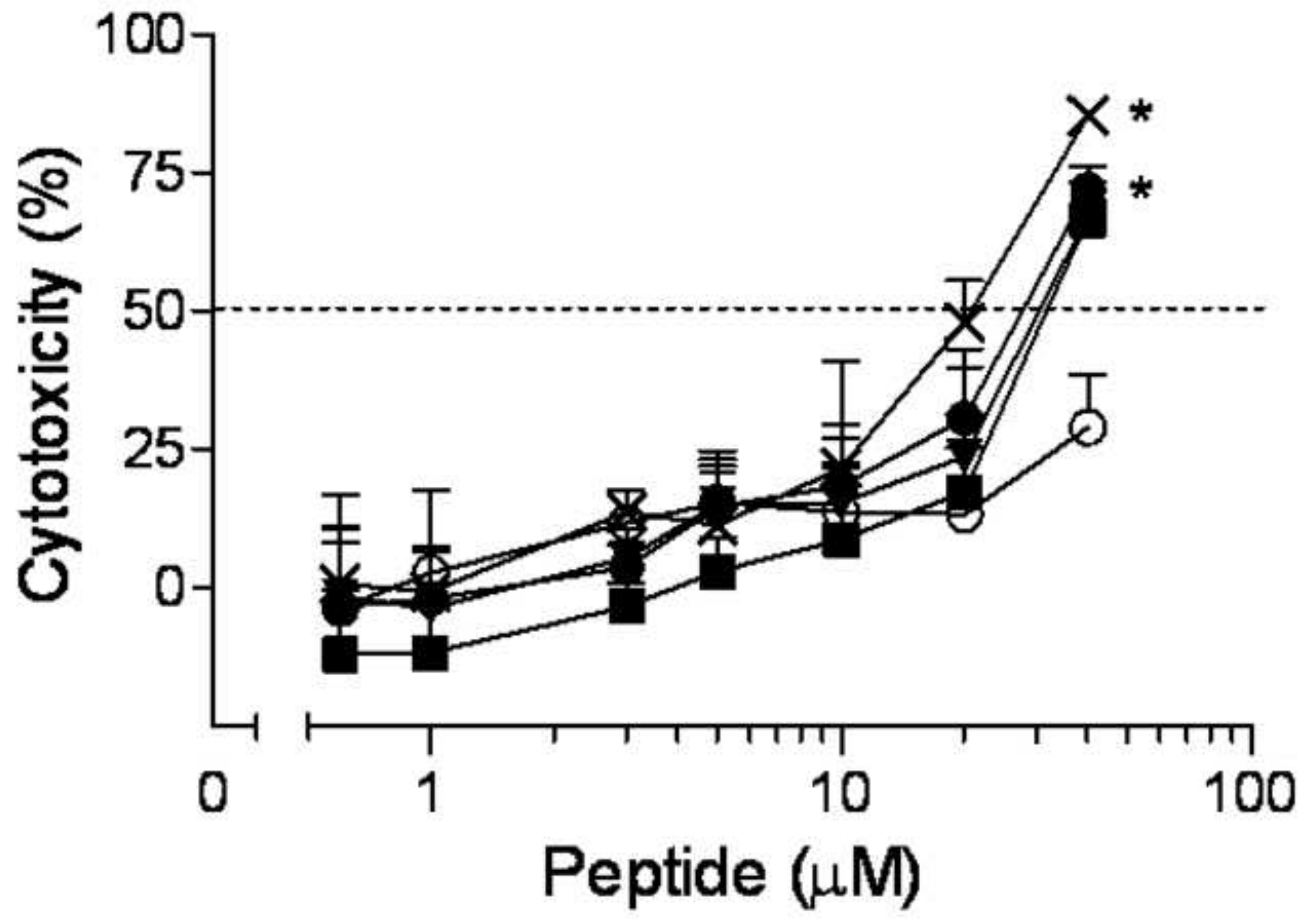



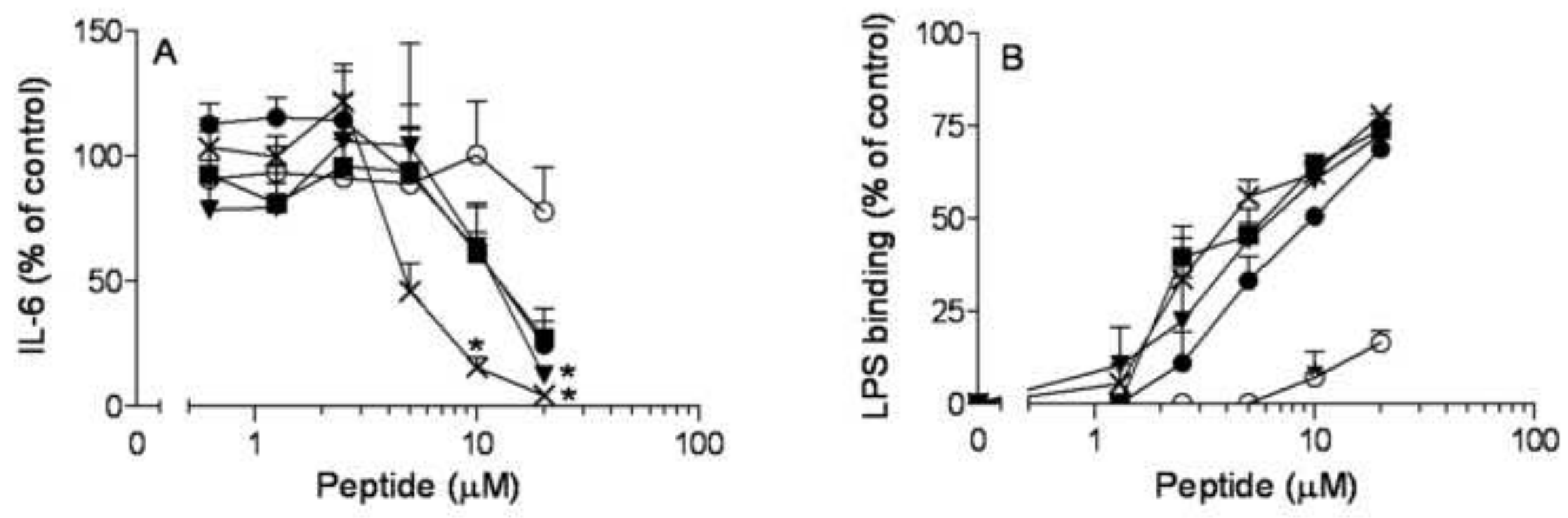